\title{
ASSEMBLAGE TURNOVERS IN MESOZOIC CALCAREOUS NANNOFOSSILS: PERIODICITY AND DISTINCTION FROM THE TERMINAL CRETACEOUS EVENT.
}

BERGEN, James, Amoco Production Company, P. O. Box 3092, Houston, TX 77253.

Long-term cycles are evident in the stratigraphic distribution(appearances/extinctions) and dominance changes of Mesozoic calcareous nannofossils. These assemblage turnovers correspond to major episodes of biological extinction recognized in inverterbrate genera and families. The identified Mesozoic nannofossil assemblage turnovers are gradual, in contrast to the well-documented and geologically instantaneous terminal Cretaceous event. Such continuity indicates a non-catatrophic cause and suggests that these turnovers are unrelated to the terminal Cretaceous "accident". Their timing instead corresponds to interpreted sea level trends and paleoceanographic changes in the sections studied.

Current evidence is based on a limited number of sections spanning the Pliensbachian to Cenomanian, although published literature and a thorough analysis of the Cenomanian show that these turnovers can be recognized over a wide geographic area. These preliminary conclusions are based on detailed sample analyses of marine sections selected for their nannofossil content. This has eliminated any taxonomic or preservational bias and problems related to compiled literature ranges.

Major dominance changes are recorded in the Pliensbachian, Bajocian, Tithonian, and Aptian. The Pliensbachian turnover is evident at the family and ordinal level, whereas the younger dominance changes occur at the generic level. A major diversification during the Pliensbachian resulted in the replacement of the Jurassic Family Crepidolithaceae by the important Jurassic placolith families. The Bajocian and Tithonian turnovers were initiated by dominance changes within the common imbricate placolith family, Ellipsagelosphaeraceae. The Tithonian turnover was most dramatic including: (1) a major diversification near the Jurassic/Cretaceous boundary; (2) the extinction of several genera; and (3) the establishment of a dominant low latitude assemblage (Nannoconus, Conusphaera, Micrantholithus). Species appearances and extinctions characterize the Cretaceous turnovers. There was an increase in species extinctions during the Hauterivian, Aptian, and Cenomanian. The Aptian also includes the extinction of the aforementioned low latitude assemblage and the subsequent diversification and radiation of more cosmopolitan floras, which continued until the end of the Albian. The highest number of nannofossil species extinctions within any Mesozoic stage (except for the terminal Cretaceous) are recorded in the Cenomanian. Although several of these species extinctions are associated with the Cenomanian/Turonian boundary anoxic event, most preceeded this event. 